\title{
ANALISIS PROSES PEMBELAJARAN BERBASIS MASALAH (PROBLEM BASED LEARNING) MATEMATIKA DENGAN PENDEKATAN ILMIAH (SCIENTIFIC APPROACH ) DI SMA NEGERI 1 JOGOROGO KELAS X TAHUN PELAJARAN 2013 / 2014 KABUPATEN NGAWI
}

\author{
Arum Dwi Rahmawati ${ }^{1}$ Riyadi $^{2}$, dan Sri Subanti ${ }^{3}$ \\ Prodi Magister Pendidikan Matematika, PPS Universitas Sebelas Maret Surakarta
}

\begin{abstract}
The purpose of this research was to describe the planning, implementation process of learning undertaken by teachers of mathematics and constraints experienced during the process of mathematical problem-based learning with a scientific approach in class X SMAN 1 Jogorogo. This research was a qualitative study. These subject are taken using purposive sampling. The subjects of this study were the teacher math in class X. Data collection techniques in this study were documentation, interviews and observations. Techniques to validate that the data source triangulation and triangulation time. The data analysis technique used was the concept of Miles and Huberman consists of data reduction, data display, and conclusion. The results showed that the planning process of mathematical problem-based learning with a scientific approach was not maximal yet, seen in the preparation of lesson plans which teachers only see examples of other schools and only see a reference to the syllabus. Implementation of the learning process is done the math teacher in class X SMAN 1 Jogorogo was not maximal yet. Visible in the indicator $5 \mathrm{M}$ on core activities are observing, asking, gather information, and communicate their associates have not done all. In observing the activities of students had no difficulty, however, go into the next phase indicator and students are still difficulties in doing so. In the event of problem making students ask questions, lack of motivation and imagination. Collect information on the activities of students also have difficulty in learning resources are used only for math books grade students associate X. At this stage also looks still difficulty in processing information, although sometimes the teacher has given direction that the students tried to process the information that has been obtained. At that last stage quite well in communicating the results, good enough student responses revealed the results even though the teacher had to call one of the students without first. Overcoming the problems found in the process of mathematical problem-based learning with a scientific approach to teacher always gives motivation at any stage of learning and trying to develop a problem-based learning with a scientific approach.
\end{abstract}

Keywords: PBL, Scientific Approach

\section{PENDAHULUAN}

Kurikulum menurut Undang-undang Nomor 20 Tahun 2003 Pasal 1 Ayat (19) adalah seperangkat rencana dan pengaturan mengenai tujuan, isi dan bahan pelajaran serta cara yang digunakan sebagai pedoman penyelenggaraan kegiatan pembelajaran untuk mencapai tujuan pendidikan. Pengembangan kurikulum menjadi amat penting 
sejalan dengan kontinuitas kemajuan ilmu pengetahuan, teknologi dan seni budaya serta perubahan masyarakat pada tataran lokal, nasional, regional dan global di masa depan. Aneka kemajuan dan perubahan itu melahirkan tantangan internal dan eksternal di bidang pendidikan dalam hal ini mata pelajaran matematika khususnya.

Dalam rangka melaksanakan isi Kurikulum 2013 serta upaya meningkatkan mutu proses pembelajaran, selama ini pengetahuan hanya disampaikan untuk selanjutnya diharapkan penyampaian pengetahuan menuju pertukaran pengetahuan. Supaya pembelajaran di dalam kelas menarik dan penuh makna, guru perlu mendesain rencana pembelajaran yang memungkinkan siswa berinteraksi aktif dalam pembelajaran. Begitu pula dalam pembelajaran matematika yang selama ini dianggap sebagai pembelajaran yang sulit dan membosankan. Motivasi serta minat belajar siswa kurang. Padahal pembelajaran matematika mempunyai peranan penting dalam mengembangkan keterampilan dan berpikir logis, sistematis, dan kreatif. Hal ini, karena matematika mempunyai fungsi untuk mengembangkan kemampuan menghitung, mengukur dan menggunakan rumus matematika yang diperlukan dalam kehidupan sehari-hari. Untuk itu kreativitas guru dalam proses pembelajaran matematika agar dapat menarik dan tidak membosankan sangat diperlukan (Depdikbud, 2013).

Namun, banyak siswa menganggap matematika sebagai materi yang sulit untuk dipelajari. Selain itu, banyak siswa mempunyai sikap pesimis serta motivasi yang kurang dalam belajar matematika. Akibatnya, prestasi belajar matematika siswa rendah. Indikator yang digunakan sebagai acuan untuk menyatakan keberhasilan dalam pembelajaran adalah daya serap siswa terhadap suatu materi yang diberikan.

Analisis hasil Trend In International Mathematics and Science Study (TIMSS) tahun 2007 dan 2011 di bidang matematika dan IPA untuk peserta didik kelas 2 SMP untuk bidang matematika menunjukkan hasil lebih dari 95\% peserta didik Indonesia hanya mampu mencapai level menengah, sementara misalnya di Taiwan hampir 50\% peserta didiknya mampu mencapai level tinggi dan advance. Dari hasil ini dapat disimpulkan bahwa yang diajarkan di Indonesia berbeda dengan apa yang diujikan atau yang distandarkan di tingkat internasional.

Hal tersebut hendaknya menjadi latar belakang tercipta pengembangan dalam pembelajaran matematika. Salah satu solusi yang mungkin akan membantu yakni dengan melakukan analisis terhadap sebuah metode pembelajaran yang digunakan pada sebuah kurikulum. Diharapkan dengan adanya analisis tersebut dapat membantu pencapaian 
tujuan dari sebuah pembelajaran, serta tidak menutup kemungkinan analisis tersebut dapat digunakan sebagai dasar untuk melakukan pengembangan dari sebuah strategi pembelajaran.

Pembelajaran berbasis masalah (Problem based Learning) merupakan salah satu jembatan untuk menciptakan pembelajaran yang aktif. Pembelajaran ini dimulai (1) mengeksplorasi dan memecahkan masalah untuk menciptakan, menggabungkan dan menggeneralisasi pengetahuan; (2) berpusat pada siswa; (3) kegiatan untuk menggabungkan pengetahuan baru dan pengetahuan yang sudah ada (Kemendiknas, 2013). Pelaksanaan pembelajaran berbasis masalah akan lebih baik ketika ada sebuah pendekatan pembelajaran yang mendukung, dalam konteks ini pendekatan yang dimaksud yakni pendekatan ilmiah. Dengan pembelajaran dengan menggunakan pendekatan ilmiah diperlukan seorang guru yang dapat mengutamakan aspek pengamatan, penalaran, penemuan, yaitu menggunakan pendekatan ilmiah. Pendekatan ilmiah (scientific appoach) dalam pembelajaran sebagaimana dimaksud meliputi mengamati, menanya, menalar, mencoba, membentuk jejaring. Proses pembelajaran menyentuh tiga ranah, yaitu sikap, pengetahuan dan keterampilan. Proses hasil belajar menggunakan penilaian autentik (Authentic Assessment) yaitu pengukuran yang bermakna secara signifikan atas hasil belajar peserta didik untuk ranah sikap, keterampilan dan pengetahuan. Selama ini praktek pelaksanaan pembelajaran dengan menggunakan pendekatan ilmiah sudah sering disarankan oleh pemerintah. Misalnya dengan dianjurkan penggunaan pendekatan kontekstual dalam proses pembelajaran. Komponen dalam pendekatan kontekstual sangat 'dekat' dengan langkah-langkah pada pendekatan ilmiah (Permendikbud, 2013)

Selama ini pendekatan ilmiah populer digunakan dalam proses pembelajaran sains. Pendekatan ilmiah (scientific approach) dalam pembelajaran matematika sama seperti pada mata pelajaran lain yaitu meliputi menggali informasi melalui pengamatan, bertanya, percobaan, kemudian mengolah data atau informasi, menyajikan data atau informasi, dilanjutkan dengan menganalisis, menalar, kemudian menyimpulkan, dan mencipta. pelaksanaan pembelajaran tersebut membutuhkan kelengkapan pembelajaran yang sesuai dengan bahan ajar dan pelaksanaan pembelajaran. Akan tetapi, hal tersebut menimbulkan masalah bagi guru yang belum memahami pembelajaran ini untuk dapat melaksanakan sebagai salah satu metode pembelajaran. Oleh karena itu, diperlukan analisis terhadap pembelajaran berbasis masalah dengan pendekatan ilmiah sehingga 
analisis tersebut akan memberikan informasi apakah guru dapat melakukan metode tersebut dan bagaimana dapat dipergunakan guru pada proses pembelajaran sehingga tujuan pembelajaran dapat tercapai.

Penelitian-penelitian yang sudah dilakukan antara lain: Graff dan Kolmos (2003) mengungkapkan bahwa PBL secara luas dianggap sebagai metode yang sukses dan inovatif untuk pendidikan teknik karena dalam kurikulum PBL menjadi pembelajar seumur hidup untuk mengambil tanggung jawab untuk proses belajar mereka sendiri. Sejalan pula dengan Harvey, Pourshafie, and Reyes (2013) menyatakan bahwa proses PBL yang lebih luas dapat menciptakan peluang untuk mengembangkan pengetahuan yang bermakna, sikap dan keterampilan yang berkaitan dengan pembelajaran kolaboratif, sehingga dapat membangun pengetahuan bekerjasama yang berlangsung efektif, membantu siswa untuk membuat eksplisit hubungan antara sikap terhadap kerjasama dan mencapai hasil pembelajaran, dan mengidentifikasi keterampilan kolaboratif khusus yang diperlukan oleh siswa, dan diperoleh melalui hasil kerjasama kelompok.

Berdasarkan uraian sebelumnya, penulis tertarik untuk mengadakan penelitian berupa analisis proses pembelajaran berbasis masalah (Problem Based Learning) dengan pendekatan ilmiah (scientific Approach) karena sebagian guru dianggap belum mampu menerapakan atau menggunakan metode pembelajaran berbasis masalah matematika dengan pendekatan ilmiah pada kurikulum 2013.

\section{METODE PENELITIAN}

Penelitian ini dilakukan untuk mendeskripsikan bagaimana perencanaan, pelaksanaan proses pembelajaran yang dilakukan guru matematika kelas $\mathrm{X}$ dan kendala yang dialami selama proses pembelajaran berbasis masalah matematika dengan pendekatan ilmiah. Penelitian ini termasuk penelitian kualitatif. Subjek dalam penelitian ini adalah guru matematika kelas X IPA1 dan X IPS1 di SMA Negeri 1 Jogorogo Kabupaten Ngawi. Teknik pengambilan subjek penelitian ini adalah purpossive sampling. Subjek diambil atas pertimbangan guru tersebut sudah pernah ikut pelatihan Kurikulum 2013.

Data utama penelitian ini berupa informasi tentang proses pembelajaran berbasis masalah matematika dengan pendekatan ilmiah meliputi perencanaan, pelaksanaan proses pembelajaran berbasis masalah dengan pendekatan ilmiah dan kendala yang dihadapi guru. Informasi tentang perencanaan pembelajaran matematika dalam penelitian 
ini meliputi informasi tentang proses penyusunan RPP mata pelajaran matematika kelas $\mathrm{X}$. Informasi tentang proses penyusunan RPP diperoleh dengan metode dokumentasi dan wawancara. Metode dokumentasi dilakukan untuk memperoleh dokumen-dokumen pendukung yang digunakan sebagai dasar untuk mengetahui proses penyusunan RPP. Dokumen tersebut meliputi dokumen silabus mata pelajaran matematika dan RPP mata pelajaran matematika. Dokumen-dokumen pendukung tersebut dijadikan peneliti sebagai bahan wawancara untuk menggali informasi lebih dalam tentang proses penyusunan RPP pembelajaran matematika di kelas X. Wawancara dilakukan terhadap guru matematika kelas X IPA1 dan X IPS1. Teknik analisis data yang digunakan untuk menganalisis hasil wawancara adalah dengan menggunakan konsep Miles dan Huberman, yaitu reduksi data, penyajian data, dan penarikan kesimpulan. Validasi data perencanaan pembelajaran menggunakan triangulasi sumber, yaitu dengan menyocokkan data yang diperoleh dari guru X IPA1 dan X IPS1.

Informasi tentang pelaksanaan pembelajaran matematika dalam penelitian ini difokuskan pada kegiatan inti yang meliputi kegiatan 5M yaitu mengamati, menanya, mengumpulkan informasi, mengasosiasi, dan mengkomunkasikan hasil. Informasi tentang proses pelaksanaan pembelajaran tersebut diperoleh dengan metode observasi dan wawancara. Metode observasi digunakan dalam penelitian ini adalah metode observasi pasif yang menggunakan handycam, sehingga dari hasil rekaman tersebut diperoleh transkrip kegiatan pembelajaran matematika berupa percakapan guru dan siswa serta tindakan yang dilakukan guru. Penelitian ini dilakukan sebanyak 4 kali observasi sehingga diperoleh 4 hasil rekaman kegiatan pembelajaran matematika pada waktu yang berbeda-beda. Informasi tentang kendala yang dihadapi guru diperoleh dengan cara yang sama seperti pada proses pelaksanaan pembelajaran. Berdasarkan pengamatan terhadap 4 hasil observasi, diperoleh dua rekaman terbaik yaitu rekaman pada observasi pertama dan ketiga. Metode wawancara dilakukan untuk mengkonfirmasi tentang kegiatan inti yang meliputi mengamati, menanya, mengumpulkan informasi, mengasosiasi, dan mengkomunikasi serta kendala yang dialami selama proses pelaksanaan pembelajaran berlangsung. Wawancara dilakukan terhadap guru matematika kelas X IPA1. Teknik analisis data yang digunakan adalah menggunakan konsep Miles dan Huberman, yaitu reduksi data, penyajian data, dan penarikan kesimpulan. Validasi data pelaksanaan proses pembelajaran dan kendala yang dialami menggunakan triangulasi waktu, yaitu dengan 
mencocokkan data pelaksanaan proses pembelajaran dan kendala yang dialami pada observasi pertama dan data pada observasi ketiga.

\section{HASIL PENELITIAN DAN PEMBAHASAN}

\section{Perencanaan Proses Pembelajaran Berbasis Masalah matematika dengan Pendekatan Ilmiah di kelas X}

Hasil penelitian berkaitan dengan proses Pembelajaran Berbasis Masalah dengan pendekatan ilmiah khususnya matematika terutama di kelas X IPA1, kesiapan guru dan siswa sangat diperlukan sebelum dimulainya pembelajaran. Di kelas X SMA Negeri 1 Jogorogo, sebelum pembelajaran dimulai guru matematika kelas X menyiapkan media dan sumber belajar yang diperlukan untuk membantu selama proses pembelajaran. Untuk siswa juga mempersiapkan tugas dan sumber belajar yang digunakan selama proses pembelajaran matematika.

Rencana Pelaksanaan Pembelajaran (RPP) yang digunakan guru dalam proses pembelajaran berbasis masalah dengan pendekatan ilmiah pada dasarnya sama atau sesuai dengan Kurikulum 2013 yakni dalam kegiatan inti memuat kegiatan mengamati, menanya, mengkomunikasikan, mengasosiasi, dan mengeksplorasi. Dalam kegiatan inti tersebut pada setiap kegiatan/tahap terdapat indikator-indikator yang guru dan siswa lakukan. Hasil penelitian berkaitan dengan kegiatan dalam proses Pemebelajaran Berbasis Masalah dengan pendekatan ilmiah menunjukkan bahwa guru sudah berusaha melaksanakan semua tahapan atau kegiatan yang ada dalam model pembelajaran tersebut.

Berdasarkan analisis data hasil dokumentasi dan wawancara dengan guru kelas X SMA Negeri 1 Jogorogo terdapat kesamaan bahwa guru tidak menyusun RPP sendiri dan mengembangkannya. Karena RPP dibuat mengacu pada silabus namun dibuat berdasarkan contoh atau berdasar silabus yang dibuat dari sekolah yang lain. Alasan guru tidak menyusun dan mengembangkan RPP sendiri pada K-13 ini karena guru masih kesulitan mengubah pola pikir yang masih terbiasa menggunakan kurikulum KTSP. Hal tersebut tidak sejalan dengan Permendikbud (Peraturan Menteri Pendidikan dan Kebudayaan Republik Indonesia) nomor 70 tahun 2013. Undang-undang Nomor 20 tahun 2003 tentang Kurikulum 2013 bertujuan untuk mempersiapkan manusia Indonesia agar memiliki kemampuan hidup sebagai pribadi dan warga negara yang beriman, produktif, kreatif, inovatif, dan 
afektif serta mampu berkontribusi pada kehidupan bermasyarakat, berbangsa, bernegara, dan peradaban dunia. Oleh karenanya seharusnya guru dituntut lebih kreatif dan inovatif, tujuannya supaya pembelajaran berlangsung secara interaktif, inspiratif, menyenangkan, menantang, memotivasi peserta didik untuk berpartisipasi aktif, serta memberikan ruang yang cukup bagi prakarsa, kreativitas, dan kemandirian sesuai dengan bakat, minat, dan perkembangan fisik dan psikologis peserta didik.

\section{Pelaksanaan Pembelajaran Berbasis Masalah matematika dengan Pendekatan}

\section{Ilmiah di kelas X}

Tahap kedua dalam pembelajaran menurut standar proses yaitu pelaksanaan pembelajaran yang meliputi kegiatan pendahuluan, kegiatan inti, dan kegiatan penutup. Guru membuka dengan salam dan bertanya terkait tugas dipertemuan sebelumnya, namun jika dikaitkan dengan kegiatan 5M pada kegiatan pendahuluan belum nampak, terlihat dari siswa yang masih kurang aktif. Pada kegiatan inti pembelajaran berbasis masalah dengan pendekatan ilmiah dikategorikan menjadi lima pengalaman belajar yaitu: a) mengamati, b) menanya, c) mengumpulkan informasi, d) mengasosiasi, dan e) mengkomunkasikan.

Dimulai dari kegiatan orientasi pada masalah dan mengamati, guru memberikan sebuah permasalahan yang kemudian siswa diminta mencari pemecahannya dan siswa juga diminta membaca sumber belajar yang digunakan dalam pembelajaran. Dalam kegiatan mengorganisasikan dan menanya, pada kegiatan ini pemebentukan kelompok tidak begitu maksimal karena terbatasnya waktu, untuk memudahkan dalam pembuatan kelompok guru meminta siswa berdiskusi dengan teman satu meja.

Setelah memberikan permasalahan, guru matematika SMA Negeri 1 Jogorogo memberikan kesempatan kepada siswa untuk bertanya pada guru atau teman terkait permasalahan yang diberikan, namun dalam kegiatan ini cenderung siswa kurang aktif karena kurangnya motivasi dan keberanian bertanya atau mengemukakan gagasan atau pendapat. Usaha yang dilakukan guru yaitu mencoba menggunakan metode pembelajaran shooping dimana ide siswa dapat tertampung namun terkendala pada waktu, selain itu guru juga memberikan motivasi dan kemudian guru menunjuk salah satu siswa untuk bertanya atau sekedar mengemukakan gagasan dan pendapatnya, pancingan seperti itu dapat membuat 
siswa yang lain akhirnya berani dan mampu mengeluarkan pendapat yang mereka tentang pemecahan masalah yang diberikan. Dengan itu pula komunikasi antar guru dengan siswa maupun siswa dengan siswa dapat berjalan lebih baik sehingga dapat pula menciptakan suasana kelas yang mengundang rasa ingin tahu. Pada tahap ini siswa belum mampu mandiri atau pembelajaran belum berpusat pada peserta didik.

Hasil di atas berbeda dengan oleh John (2006) menyatakan sebuah pendekatan pembelajaran yang telah digunakan dengan berhasil selama lebih dari 30 tahun dan terus mendapatkan penerimaan dalam berbagai disiplin ilmu. Saat ini pembelajaran berpusat pada peserta didik. Untuk melakukan penelitian, pedekatan yang digunakan mengitegrasikan teori dan praktik serta menerapkan pengetahuan dan keterampilan untuk mengembangkan solusi yang layak untuk mendefinisikan sebuah masalah. Pada tahap berikutnya yakni membimbing penyelidikan dan mengumpulkan informasi serta menganalisis. Dalam tahap ini siswa cenderung kesulitan karena minimnya sumber belajar yang dimiliki jadi siswa hanya sebatas bertanya kepada guru atau siswa yang lebih tahu.

Tahap berikutnya yakni mengembangkan hasil karya dan mengasosiasi, pada kegiatan tersebut siswa cukup aktif ketika memang siswa sudah mulai mengetahui perkiraan pemecahan masalah yang diberikan. Namun, ketika materi dirasa sulit guru harus memberikan clue atau memberikan bantuan agar siswa mampu mengolah informasi-informasi yang telah ditemukan.

Kemudian pada tahap menganalisis, mengevaluasi dan mengkomunikasikan, pada materi seperti trigonometri guru harus menunjuk salah satu untuk menunjukan pemecahan dari permasalahan yang diberikan dan memintanya untuk menjelaskan alasannya. Dengan seperti itu siswa yang lain menjadi lebih berani bertanya dan menyampaikan hasil pengamatan dan analisis mereka terhadap permaslahan matematika yang diberikan. Secara tidak langsung sikap dalam belajar telah ditanamkan guru dalam Pembelajaran Berbasis Masalah dengan pendekatan ilmiah, hal tersebut juga menjadi salah satu alasan mengapa Pembelajaran Berbasis Masalah dengan pendekatan ilmiah dipilih yakni karena dapat mengembangkan sikap belajar yag baik.

Sejalan dengan Rakhshanda (2013) menunjukkan bahwa Problem Based Learning bila digunakan sebagai metode pembelajaran tidak secara signifikan mendorong berpikir kritis dan keterampilan pemecahan masalah, sedangkan itu tidak 
begitu mempengaruhi pengetahuan. Di sisi lain, mengajar melalui pendekatan tradisional lebih meningkatkan pengetahuan tetapi tidak meningkatkan pemikiran kritis dan masalah keterampilan pemecahan masalah. PBL merupakan alat pembelajaran yang efektif untuk mendorong pemikiran kritis dan keterampilan pemecahan masalah. Sejalan dengan penelitian Sharifah dan Lee (2005) menyatakan hasil penilaian menunjukkan bahwa metode Problem Based Learning memiliki dampak positif secara keseluruhan pada sikap siswa.

Dalam penilaian yang dilakukan guru matematika kelas X SMA Negeri 1 Jogorogo yakni memantau kemajuan siswa selama pembelajaran berlangsung, memberikan apresiasi terhadap apa yang sudah dikerjakan baik berupa pujian ataupun nilai. Kemudian diakhir pembelajaran selalu meberikan tugas ataupun pekerjaan rumah untuk siswa dan meminta siswa memepelajari materi yang akan dipelajari dipertemuan berikutnya. Dalam kegiatan penutup baik dalam observasi pertama dan ketiga pada proses pembelajaran berbasis masalah dengan pendekatan ilmiah di SMA Negeri 1 Jogorogo ini guru hanya melakukan kegiatan menyimpulkan bersama-sama dengan siswa tentang apa yang telah dipelajari dan memberikan PR dan menutup dengan salam.

\section{Faktor Kendala dalam Pembelajaran Bernasis masalah dengan pendekatan ilmiah di kelas $\mathrm{X}$}

Secara umum faktor-faktor yang mempengaruhi proses belajar anak dibedakan menjadi faktor internal dan faktor eksternal. Kedua faktor tersebutlah yang mempengaruhi hasil belajar anak. Berikut akan diuraikan tentang kedua faktor penghambat belajar. Faktor kendala yang dialami oleh guru matematika kelas $\mathrm{X}$ SMA Negeri 1 Jogorogo masih pada penerapan kurikulum baru yakni Kurikulum 2013, karena sebagian guru masih mengacu pada KTSP dan managemen waktu dalam pembelajaran karena kurangnya managemen waktu sehingga tahapan yang ada dalam Pembelajaran Berbasis Masalah dengan pendekatan ilmiah terkadang kurang maksimal.

Kendala yang dialami siswa yakni kurangnya motivasi dan minat dalam mengikuti pembelajaran matematika, hal tersebut dilihat dari kurangnya respon aktif siswa selama pembelajaran berlangsung karena matematika berada pada jam terakhir. Kendala pada materi, ketika siswa materi mudah siswa cenderung lebih 
aktif dan kegiatan pada Pembelajaran Berbasis Masalah dengan pendekatan ilmiah berjalan cukup baik, hal tersebut terlihat ketika materi mempelajari konsep dasar sudut. Namun, untuk materi yang dirasa sulit oleh siswa hal yang terjadi pada tahap mengasosiasi ke tahap selanjutnya siswa cenderung kesulitan.

Hasil di atas sejalan dengan paparan John (2003) yang menyatakan bahwa hasil belajar peserta didik dipengaruhi oleh waktu yang tersedia untuk mempelajari bahan pelajaran yang telah ditentukan, usaha yang dilakukan peserta didik untuk menguasai bahan pelajaran, bakat yang dimiliki peserta didik, kualitas pengajaran atau tingkat kejelasan pengajarannya, dan kemampuan peserta didik untuk mendapat manfaat yang optimal dari keseluruhan proses pembelajaran yang sedang dihadapi.

Berdasarkan pembahasan di atas pelaksanaan pembelajaran berbasis masalah dengan pendekatan ilmiah sesuai Kurikulum 2013 di kelas X IPA1 masih belum bisa dilaksanakan dengan baik hal ini terlihat pada tahapan atau indikator yang terdapat dalam kegiatan 5M yaitu mengamati, menanya, mengumpulkan informasi, mengasosiasi dan mengkomunikasikan belum bisa dicapai. Pada tahap kedua yaitu menanya siswa masih kesulitan melaksanakan indikator-indikator didalammnya. Hal tersebut terjadi karena kendala dari siswa sendiri yang masih kesulitan merumuskan atau membuat pertanyaan terkait dengan permasalahan yang diberikan.

\section{SIMPULAN DAN SARAN}

Berdasarkan hasil penelitian dan pembahasan, dapat disimpulkan pembelajaran berbasis masalah matematika dengan pendekatan ilmiah dilihat dari penyusunan RPP, guru matematika kelas $\mathrm{X}$ di SMA Negeri 1 Jogorogo belum mengembangkan sepenuhnya. Hal ini terlihat dari penyusunan RPP yang masih hanya melihat RPP dari sekolah lain dan melihat silabus. Proses pelaksanaan pembelajaran matematika berbasis masalah dengan pendekatan ilmiah di kelas X SMA Negeri 1 Jogorogo belum berjalan maksimal. Ini terlihat pada indikator-indikator pada setiap tahapan kegiatan inti dalam Pembelajaran Berbasis Masalah dengan pendekatan ilmiah belum semua tercapai. Pelaksanaan Pembelajaran Berbasis Masalah dengan pendekatan ilmiah melalui tiga tahap pendahuluan, inti, dan penutup. Pada tahap pendahuluan dan penutup guru cukup lancar. Pada tahap inti kegiatan pembelajaran guru dan siswa masih belum maksimal. Hal tersebut terlihat dari indikator yang terdapat pada kegiatan inti Pembelajaran 
Berbasis Masalah belum terpenuhi semua. Pada tahap pertama lancar, masuk ke tahap berikutnya siswa mulai kesulitan. Misalnya pada kegiatan organisasi dan proses tanyajawab, pembuatan kelompok dilakukan oleh guru dengan meminta siswa berdiskusi dengan teman satu meja. Guru memberikan rangsangan kepada siswanya dengan jalan menunjuk salah satu siswa untuk mengajukan pertanyaan atau sekedar memberikan ide. Hal tersebut terbukti dapat membantu siswa dalam melatih sikap percaya diri dan berani mengeluarkan pendapat, hal tersebut terlihat ketika ada salah satu siswa bertanya terkait permasalahan trigonometri. Tahap membimbing dan mengumpulkan informasi, siswa masih kesulitan karena terbatasnya sumber belajar. Pada tahap mengasosiasi dan mensintesis, guru memberikan rangsangan berupa pertanyaan atau sedikit penjelasan karena siswa kesulitan membuat dugaaan dan mengolah informasi. Tahap yang terakhir mengkomunikasikan, siswa cenderung pasif karena kurang memilki sikap percaya diri. Namun, ketika guru meminta salah satu siswa untuk menyampaikan hasilnya di depan kelas, keaktifan siswa yang lain cukup bagus. Faktor kendala yang dialami oleh guru matematika kelas X SMA Negeri 1 Jogorogo yaitu masalah waktu pembelajaran dimana bidang studi matematika dilaksanakan pada jam terakhir, dan sulitnya mengubah pandangan guru yang masih sedikit terbawa dengan kurikulum sebelum Kurikulum 2013. Kendala dari siswa yaitu masih kurangnya motivasi belajar matematika dan sikap percaya diri dalam mengeluarkan pendapat, disertai kurangnya referensi sumber belajar yang dipergunakan siswa dalam pembelajaran.

Berdasarkan kesimpulan peneliti dapat memberikan saran yaitu guru perlu terus meningkatkan profesionalisme, kreativitas, dan kompetensinya dalam mendesain pembelajaran matematika dan mengembangkan perangkat pembelajaran sendiri sesuai Kurikulum 2013. Guru juga perlu mengguanakan model pembelajaran yang dikembangkan dalam Kurikulum 2013 serta mampu memanfaatkan media yang mendukung dalam pelaksanaan pembelajaran matematika. Guru harus mampu memberikan motivasi yang baik, sehingga minat siswa meningkat dalam belajar matematika dan memiliki sikap belajar yang baik, serta menumbuhkan rasa ingin tahu.

\section{DAFTAR PUSTAKA}

Ahmed,Y. 2013. "Problem Based Learning as an Instructional Method". Journal of the college of Physicians and Surgeons Pakistan. 23. (1). 83-85.

Depdikbud. 2013. Bahan Uji Publik Kurikulum 2013. Jakarta: Depdiknas. 
Depdikbud. 2013. Dokumen Kurikulum 2013. Jakarta: Depdiknas.

Graff, D. E. dan Kolmos, M. 2003. "Caracteristic of Problem-Based Learning". Int. J. Engng. Ed. 2003. 19 (5)

Harvey, M. R., Pourshafie, T., and Reyes, S. W. 2013. "What Teacher Education Students Learn About Collaboration from Problem-Based Learning". Journal of Problem Based Learning in Higher Education. 1 (1).

John, R. S. 2006. "Overview of Problem-based Learning: Definitions and Distinctions". Interdisciplinary Journal of Problem-based Learning. 1 (1).

Kemendikmbud. 2013. Modul Pelatihan Kurikulum 2013. Jakarta: Badan Pengembangan Sumber Daya Manusia Pendidikan dan Kebudayaan dan Penjaminan Mutu Pendidikan, Kembikbud.

Rakhshanda, T. 2013. "Effectiveness of problem based learning for acquition of knowledge and critical thinking". Journal of the college of Physicians and Surgeons Pakistan. 23 (1). 42-46.

Sharifah, N. A. S. Z dan Lee, S. E. 2005. 'Integrating Problem-Based Learning (PBL) in Mathematics Method Course". Vol . 3, Issue 1. 